\title{
DIE REG OP KOLLEKTIEWE BEDINGING: BELANGRIKE VERWIKKELINGE
}

\section{$1 \quad$ Inleiding}

Ongeveer honderd en vyftig jaar gelede is die volgende, treffende en besonder toepaslike woorde in die klassieke werk van Mary Elizabeth Braddon vervat:

"There can be no reconciliation where there is no open warfare. There must be a battle, a brave, boisterous battle ... before there can be peaceful treaties and enthusiastic shaking of hands" (Braddon Lady Audley's Secret (1862) 250 (Wirago Modern Classics 1985 uitg).

Hierdie omstrede en uiters aktuele onderwerp van die reg op kollektiewe bedinging (sien ook a 23(5) van die Grondwet van 1996) het alreeds oor die afgelope dekade baie aandag van die howe en skrywers geniet het - veral in die lig van verskeie gebeure gedurende die onmiddellike verlede. Die afgelope aantal jare het die SA Weermag gesukkel met die hantering van soldate op arbeidsverhoudinge-vlak - soos wat verskeie protesaksies, stakingsoptredes van soldate, onderlinge lastereise teen mekaar en die onlangse Wysigingswet op Verdediging van 2011 onteenseglik laat blyk het (teen hierdie agtergrond en in hierdie konteks moet die Wysigingswet op Verdediging van 2011 dan ook verstaan word). Eweneens het ontwrigtende stakingsoptrede gedurende die tweede helfte van 2012 in die mynbousektor en die Wes-Kaapse landboubedryf duidelik getuig dat arbeidswetgewing tekort geskiet het om die onderhawige probleme sinvol te hanteer of te voorkom het.

Die Konstitusionele Hof se betrokkenheid by omstrede arbeidsaangeleenthede en sy eie bydrae tot die kwantum van kontroversie is egter nie ongewoon nie (sien, oa, In re Certification of the Constitution of the Republic of South Africa 19961996 ILJ 821 (KH); SA National Defence Union v Minister of Defence 1999 ILJ 2265 (KH); Hoffmann v SA Airways [2000] 12 BLLR $1365(\mathrm{KH})$; Fredericks $v$ MEC for Education \& Training, Eastern Cape 2002 ILJ 81 (KH); NEHAWU v University of Cape Town 2003 ILJ 95 (KH); NUMSA v Bader Bop (Pty) Ltd [2003] 2 BLLR 103 (KH); Dudley $\checkmark$ City of Cape Town 2004 ILJ 991 (KH); Minister of Finance $v$ Van Heerden [2004] 12 BLLR 1181 (KH); NK v Minister of Safety \& Security 2005 ILJ 1205 (KH); Sidumo v Rustenburg Platinum Mines 2007 ILJ 2405 (KH); Chirwa v Transnet Ltd 2008 ILJ 73 (KH); Du Toit v Minister for Safety \& Security of Republic of SA 2009 ILJ 2001 (KH); Gcaba v Minister for Safety \& Security 2010 ILJ 296 (KH); Billiton Aluminuim t/a Hillside Aluminium v Khanyile 2010 ILJ 273 (KH); Aviation Union of SA v SA Airways (Pty) Ltd 2011 ILJ 2861 (KH); F v Minister of Safety \& Security 2012 ILJ 93 (KH); SA Transport \& Allied Workers Union v Garvas 2012 ILJ $1593(\mathrm{KH})$; en SA Transport \& Allied Workers Union v Moloto NO 2012 ILJ 2549 (KH)). 
In die onlangse beslissing van Gcaba $v$ Minister for Safety \& Security (supra) is die volgende insiggewende uitlating oor regswoelinge en skerp meningsverskille op arbeidsregtelike terrein, dapper maar realisties, in hierdie Hof soos volg beskrywe: "Yet the legislature, courts, legal representatives and academics often create complexity and confusion rather than clarity and guidance. In the case of fairly new legislation based on a young Constitution this is perhaps understandable" (301 par [2], my kursivering). Hierdie uitlating van die $\mathrm{Hof}$ is na my mening ook ongekwalifiseerd van toepassing op die onderhawige bespreking van die reg op kollektiewe bedinging (sien ook Makambi $v$ MEC, Department of Education, Eastern Cape Province 2008 ILJ 2129 (HHA); en Tsika v Buffalo City Municipality 2009 ILJ 105 (OK)).

Die Konstitusionele Hof het in SA National Defence Union $v$ Minister of Defence (2007 ILJ 1909 (KH) (SANDU V)) ook die ongewone geleentheid gehad om hom uit te laat oor die omstrede kwessie van die reg op kollektiewe bedinging - ongewoon omdat oor hierdie onverkwiklike arbeidsregtelike dispuut die afgelope paar jaar alreeds ses uiteenlopende uitsprake gelewer is (sien South African National Defence Union v Minister of Defence 2003 ILJ 1495 (T) (SANDU I); South African National Defence Force Union v Minister of Defence 2003 ILJ 2101 (T) (SANDU II); South African National Defence Union $v$ Minister of Defence $(T)$ case no 15790/2003, 14 Julie 2003, unreported (SANDU III); en SANDU v Minister of Defence; Minister of Defence v SANDU 2006 ILJ 2276 (HHA) (SANDU IV). Alhoewel hierdie Hof nuwe gesigspunte oor die aangeleentheid geopen het en die reg in beginsel erken het, het dit nie heeltemal die polemiese onsekerheid waarin die "debat" gehul is, opgeklaar nie.

Bogemelde uitsprake het ook talle besprekings in regsgeskrifte die afgelope jare ontlok en in die geledere van skrywers was daar eweneens nie konsensus oor die aard en betekenis van die sogenaamde "reg op kollektiewe bedinging" nie en of daar selfs in beginsel so ' $n$ reg bestaan nie (sien Grogan "It Takes Two to Bargain: Military Unions March Forward" 2004 20(3) Employment Law 11; Van Jaarsveld "Die Reg op Kollektiewe Bedinging: Nog Enkele Kollektiewe Gedagtes" 2004 De Jure 349; Landman "The Duty to Bargain - An Old Weapon Pressed into Service" 2004 ILJ 39; Vettori "A Judicially Enforceable Duty to Bargain?" 2005 De Jure 382; Christianson in Currie and De Waal The Bill of Rights Handbook 5uitg (2005) 515; Van Jaarsveld "Nogeens die Reg op Kollektiewe Bedinging" 2006 De Jure 655; Cheadle "Regulated Flexibility: Revisiting the LRA and the BCEA" 2006 ILJ 692; Du Toit, Bosch, Woolfrey, Godfrey, Cooper Giles, Bosch and Rossouw Labour Relations Law 5uitg (2006) 243; Van Jaarsveld "Die Hoogste Hof van Appél en Kollektiewe Sienings oor Kollektiewe Bedinging" 2007 THRHR 299; Du Toit "What is the Future of Collective Bargaining (and Labour Law) in South Africa?" 2007 ILJ 1405; Grogan Collective Labour Law (2007) 92; Van Jaarsveld "Kollektiewe Sienings oor Kollektiewe Bedinging deur die Konstitusionele Hof" 2008 THRHR 124; Molusi "The Constitutional Duty to Engage in Collective Bargaining" 2010 OBITER 156; Van Niekerk et al Law@Work 2uitg (2012) 369; Van Jaarsveld, Fourie en Olivier Principles and Practice of Labour Law (2012) diensuitg 22 par 542; en sien ook Cheadle in Cheadle, Davis and Haysom South African Constitutional Law: The Bill of Rights (2002) 390-395). Derhalwe is onlangse uitsprake in 
Kanada en Europa oor hierdie onderwerp van verreikende belang en verg daarom verdere bespreking.

\section{Betekenis en regsposisie met betrekking tot reg op Kollektiewe Bedinging tot 1993}

Twyfel en onduidelikheid oor die betekenis van die reg om kollektief te beding, het ontstaan kort na die beslaggewing van Wiehahn-bedeling, toe bedenkinge uitgespreek is oor of daar inderdaad ' $n$ verpligting op ' $n$ party kan rus om kollektief te beding (onderhandel), veral in die lig van die feit dat die proses van kollektiewe bedinging as ' $n$ vrywillige proses beskou moet word (die sogenaamde leerstuk van "voluntarisme", sien SAAWU v Border Boxes (Pty) Ltd 1987 ILJ 467 (NH); UAMAWU v Thomsons (Pty) Ltd 1988 ILJ $266(\mathrm{NH})$; asook Thompson "On Bargaining and Legal Intervention" 1987 ILJ 1). Hierdie onsekerheid is egter gedurende 1988 opgeklaar in FAWU $v$ Spekenham Supreme (2) (1988 ILJ $628(\mathrm{NH})$ ) toe pertinent verklaar is dat "having regard to the fact that fairness is now the overriding consideration in labour relations in South Africa, it is time for the court to find firmly and unequivocally that in general terms it is unfair for an employer not to negotiate with a representative trade union" (535-537; sien ook NUM $v$ Goldfield of SA Ltd 1989 ILJ 86 (NH); Sentraal-Wes (Koöperatief) Bpk v FAWU 1990 ILJ 977 (AAH); en Photocircuit SA (Pty) Ltd v De Klerk 1991 ILJ $289(A))$.

Die Arbeidsappélhof het ook enkele jare later die geleentheid gehad om oor die aangeleentheid te besin en in MacSteel (Pty) Ltd v NUMSA (1990 ILJ 995 (AAH) 1006B; en sien Davis "Juridification of Industrial Relations in South Africa" 1991 ILJ 1181) wat in geen onduidelike terme nie soos volg beslis het: "In my view the LRA creates machinery which makes collective bargaining not only possible but also compulsory. Its aim is to avoid if possible, industrial strife and to maintain peace", 'n standpunt wat 'n jaar later die eerste keer deur die Appélafdeling bevestig is in die sleutelsaak van East Rand Gold \& Uranium Co Ltd v NUM (1991 ILJ 1221 (A)), toe soos volg beslis is: "The fundamental philosophy of the Act is that collective bargaining is the means preferred by the legislature for the maintenance of good labour relations and for the resolution of labour disputes" (vgl ook Perskorporasie van SA Bpk v MWASA 1993 ILJ 938 (AAH); SASBO v Standard Bank of SA Ltd 1995 ILJ 362 (AAH), 1998 ILJ 223 (HHA); en Cobra Watertech v NUMSA 1995 ILJ 607 (AAH)). Enkele jare later is die fundamentele reg ook onderskryf toe dieselfde Hof in Mutual \& Federal Insurance Co Ltd v Banking Insurance Finance \& Assurance Workers Union (1996 ILJ 241 (A) 247B-D) hom soos volg uitgelaat het:

"The fundamental right of employees to bargain collectively with their employers with regard to wages, conditions of employment and other matters of mutual interest is now well established in our law. It has been said that collective bargaining 'lies at the heart of the industrial relations system' (National Union of Mineworkers v Henry Gould (Pty) Ltd (1988) 9 ILJ 1149 (IC) 1154E-F); and collective bargaining has been described as the cornerstone in any labour relations system' (National Union of Mineworkers $v$ Buffelsfontein Gold Mining Co (1991) 12 ILJ 346 (IC) 351H)." 
(Hierdie sienswyse is herbevestig in SA Society of Bank Officials $v$ Standard Bank of SA Ltd 1998 ILJ 223 (HHA) 227F; en sien ook Mzeku v Volkswagen SA (Pty) Ltd [2001] 8 BLLR 857 (AAH)). Bogemelde benadering kan nog steeds onderskryf word indien egter onthou word om 'n onderskeid te tref tussen die reg op kollektiewe bedinging (met 'n meegaande verpligting om bona fide te onderhandel) wat verpligtend is en die verskillende meganismes, partye en resultate (uitkomstes) van sodanige bedinging, wat vrywillig is. Gemelde regsposisie en sienswyse is ook deur verskeie skrywers ondersteun. Brassey is heel uitgesproke oor die reg op kollektiewe bedinging en veral die meegaande verpligting om te beding:

"The most notable of these are the many provisions that embody the legislature's endorsement of collective bargaining. They encourage, indeed virtually compel, one to conclude that the promotion of collective bargaining was one of the objectives the legislature had in mind in enacting the unfair labour practice jurisdiction. This being so, it follows that it may be illegitimate and so unfair, to act in a manner subversive of collective bargaining" (Brassey, Cameron, Cheadle and Olivier The New Labour Law (1987) 149; en sien ook "Overview of the Industrial Court" in Benjamin, Jacobus en Albertyn Strikes, Lock-outs and Arbitration in SA Labour Law (1989) 17).

Die rede vir die weestandigheid teen die verpligting om kollektief te beding, veral deur die eksponente van die sogenaamde leerstuk van "voluntarisme", is op die volgende realistiese wyse deur Brassey verduidelik:

"[T]he case for voluntary bargaining is generally espoused by employers, not by unions. This is no coincidence. Unions see collective bargaining as important to the advancement of their members' interests. Many employers, seeing it in exactly the same way, have no wish for that advancement. Collective bargaining for them, is a Trojan horse. If they agree to it, the union will be 'in the factory'. Its status for the workforce will be enhanced. It will insist on being consulted before action is taken. And it will forever be calling its members out on strike. Managerial prerogative will be lost and gone, and in its place will be industrial strife. Much better, they believe, to resist unionism at the outset, to scotch the snake, as it were, while it is still without ... These people, in short, want bargaining to be voluntary because they do not want to bargain at all, and they do not want to bargain because they do not like unions" (Brassey et al The New Labour Law 151).

Soortgelyke bedenkinge is ook deur Davis ("Voluntarism and South African Labour Law - are the Queensbury Rules an Anachronism?" 1990 Acta Juridica 67) uitgespreek.

\section{Die interim en finale grondwette}

Die Interim en die finale Grondwette bevat duidelike bepalings in verband met die reg op kollektiewe bedinging. Artikel 27(3) van die Interim Grondwet 1993 lui soos volg: "Werkers en werkgewers het die reg om te organiseer en kollektief te beding." (Die Engelse teks lui: "Workers and employers shall have the right to organise and bargain collectively.") Die Grondwet 1996 verleen egter erkenning aan die reg in ander geformuleerde terme wanneer soos volg in artikel 23(5) bepaal word: "Elke vakbond, elke werkgewersorganisasie en werkgewer het die reg om aan kollektiewe bedinging mee te doen." (Die Engelse teks lui as volg: "Every trade union, employers' organisation and employer has the right to engage in collective bargaining.") 
Dit is onduidelik waarom die formulerings van hierdie fundamentele reg in die twee grondwette van mekaar verskil. Brassey en Cooper (in Chaskalson et al Constitutional Law of South Africa (1998) 30) het nietemin probeer om die verskille soos volg te verduidelik:

"The 'right to engage' in collective bargaining in the final Constitution differs significantly from the right under the interim Constitution, which gave workers and employers the 'right' to bargain collectively. The difference between the two rights has been described as the difference between a right and a freedom .... According to this interpretation, a right to collective bargaining would imply a correlative duty to bargain, in contrast to a right to 'engage' in collective bargaining where there is no duty to ensure its protection, but merely an obligation not to interfere with the exercise of the right .... The distinction between the right to collective bargaining and the right to 'engage' in collective bargaining is a fine one. By itself, the wording is far from conclusive, leaving the door open to a constitutional challenge ..."

Die skrywers erken dus dat die onderskeid tussen 'n reg en 'n vryheid om kollektief te beding, delikaat is en hom leen tot 'n ander uitlegbetekenis en vatbaar vir konstitusionele bevraagtekening is - wat inderdaad later in twee uitsprake van die Konstitusionele Hof gebeur het. Gemelde differensiasie van die skrywers is egter nie oortuigend nie. Die onderskeid is dan inderdaad later na die Hoogste Hof van Appél verwys in SANDU v Minister of Defence; Minister of Defence v SANDU (supra; en sien ook Van Jaarsveld 2008 THRHR 124) nadat dit vroeër in die hof a quo erken is (sien ook Van Jaarsveld 2004 De Jure 355), veral nie in die lig van die duidelike bewoording van artikel 23(5) van die Grondwet en sy voorganger-artikel 27(3) van die Interim Grondwet nie. As dit die bedoeling van die wetgewer was om nie 'n reg nie, maar slegs 'n "vryheid om aan kollektiewe bedinging mee te doen", te verleen, sou dit inderdaad so geformuleer gewees het aangesien daar in verskeie ander bepalings van die Grondwet slegs ' $n$ vryheid, en nie 'n ongekwalifiseerde reg, verleen word nie (sien, oa, art 12, 15 en 16 van die Grondwet).

\section{$4 \quad$ Wet op Arbeidsverhoudinge 66 van 1995}

Hierdie Wet (hierna verwys as "WAV") bevat in artikel 1 'n belangrike bepaling wat lui dat die eerste hoofoogmerk ("primary object") is "(a) om uitvoering te gee aan die fundamentele regte verleen in artikel 27 (van die Interim Grondwet; nou artikel 23 van die finale Grondwet) en dit te reguleer." Artikel 1 dui ook as een van die Wet se verdere hoofoogmerke die daarstelling van 'n raamwerk aan waarbinne werknemers en hulle vakbonde en werkgewers kollektief kan beding oor lone, diensvoorwaardes kan vasstel (art 1(c)(i) en om ordelike kollektiewe bedinging in die algemeen, asook op sektorale vlak, te bevorder (art 1(d)(i) en (ii)). Die betekenis van bostaande bepalings van WAV is dat dit nie alleen die reg op kollektiewe bedinging erken nie, maar selfs verder gaan deur te bepaal dat, as een van die hoofoogmerke, moet daar ook aan uitvoering gegee moet word as ' $n$ fundamentele reg, dit wil sê nie slegs as 'n gewone reg nie - laat staan nog 'n sogenaamde "vryheid". WAV verskaf na my mening verder ook, in navolging van bogemelde hoofoogmerke, uitvoerige bedingingstrukture, skryf uitgebreide prosedures voor en lê vereistes ten opsigte van bedingingsrade, stakings, uitsluitings, ensovoorts neer, ten einde sinvol 
beslag en uitvoering aan die reg op kollektiewe bedinging te gee (sien ook Du Toit et al Labour Relations Law 243-245; en Vettori 2005 De Jure 386390).

Die interaksie tussen die Grondwet en die arbeidswetgewing van 1995 is duidelik deur Steenkamp, Stelzner and Badenhorst ("The Right to Bargain Collectively" 2004 ILJ 944-945) ingesien:

"As a member state of the ILO, South Africa has committed itself to fulfilling its obligations in terms of public international law, including the above, and has now given effect to its commitment by enshrining the right to collective bargaining as a constitutional right, and by providing extensively for collective bargaining in labour legislation. The right to collective bargaining is entrenched in $s$ 23(5) of the South African Constitution ... Moreover, as a fundamental right, the state of South Africa is constitutionally bound to 'respect, protect, promote and fulfil' the right to collective bargaining. A reading of the current Labour Relations Act 66 of 1995 (LRA), makes it clear that the Act is aimed at doing just that."

(Sien ook ivm die positiewe erkenning van die reg op kollektiewe bedinging Joubert (red) LAWSA Volume 13 2uitg (2009) par 471; Van Jaarsveld et al Principles and Practice of Labour Law par 542 en sien ook die benadering tot die onderhawige problematiek van Du Toit et al Labour Relations Law 229-230; en Grogan Collective Labour Law 92).

Die feit dat WAV nie 'n direkte bepaling ten opsigte van 'n reg op kollektiewe bedinging bevat nie, het sommige skrywers daartoe genoop om te verklaar dat die wetgewer ten aansien van kollektiewe bedinging ' $n$ totaal vrywillige benadering aanvaar het. So verklaar Brassey:

"In seeking to promote a framework within which employees and employers can collectively bargain, the Act adopts an unashamedly voluntarist approach: it does not prescribe to the parties whom they should bargain with, what they should bargain about, or whether they should at all. In this regime the courts have no right to intervene and influence collectively bargained outcomes. These actions must depend on the relative power of each party to the bargaining process" (Employment Law and Labour Law Volume 3A (1999)

$1: 8$; my beklemtoning).

Hierdie benadering kan bevraagteken word omdat daar nie onderskei word tussen die fundamentele reg om kollektief te beding, aan die een kant, en aan die ander kant die meganismes (prosesse) om die reg te laat realiseer en die uitkomstes daarvan nie. Laasgenoemde aspekte is inderdaad vrywillig en hang van die omstandighede en partye af, soos in enige kontraktuele situasie die geval is. Dit val vreemd op dat werkers nie 'n reg op 'n fundamentele vereiste soos kollektiewe bedinging besit nie, maar wel ten opsigte van bepaalde regte van minder belangrike aangeleenthede verkry soos erkenning as vakbond, aftrekking van ledegeld, openbaarmaking van inligting.

Cheadle sien ook die oplossing vir die beweerde weerspreking tussen artikel 23(5) van die Grondwet en die kollektiewe bedinging-bepalings van die WAV in die onderskeid tussen 'n positiewe reg om te beding en ' $n$ blote vryheid daartoe (Cheadle, Davis and Haysom South African Constitution Law: the Bill of Rights 390-395; en Cheadle 2006 ILJ 692). Hy is van mening dat artikel $23(5)$ slegs 'n vryheid, en nie 'n reg nie tot kollektiewe 
bedinging, verleen nie (395). Vettori (2005 De Jure 390-394) is ook van mening dat die Grondwet slegs ' $n$ vryheid op kollektiewe bedinging (sonder 'n meegaande verpligting om te onderhandel) verleen.

\title{
$5 \quad$ Sienswyse van die Konstitusionele Hof tot 2006
}

In 1996 is Die Konstitusionele Hof versoek om die Grondwet te sertifiseer. Die Hof stel dit duidelik wat sy siening oor die onderhawige vraagstuk is in In re Certification of the Constitution of the Republic of South Africa 1996 (supra par 64) wanneer soos volg verklaar word:

\begin{abstract}
"The second objection levelled at NT (new text) 23 is based on the failure to entrench the right of individual employers to engage in collective bargaining. The objection was based on CP (constitutional principles) XXVIII which provides that the right to employers ... to engage in collective bargaining shall be recognised and protected ... As stated above, collective bargaining is based on the need for individual workers to act in combination to provide them collectively with sufficient power to bargain effectively with employers. Individual employers, on the other hand, can engage in collective bargaining with their workers and often do so. The failure by the text to protect such a right represents a failure to comply with the language of CP XXVIII which specifically states that the right of employers to bargain collectively shall be recognised and protected."
\end{abstract}

In NUMSA v Bader Bop (Pty) Ltd (2003 ILJ 305 (KH)) gaan die Konstitusionele Hof selfs verder en wys nie alleen op die bestaan van die reg op kollektiewe bedinging nie, maar ook die belang daarvan wanneer regter O'Regan soos volg verklaar:

"The entrenchment of the right of workers to form and join trade unions and to engage in strike action, as well as the right of trade unions, employers ... to engage in collective bargaining, illustrates that the Constitution contemplates that collective bargaining between employers and workers is a key to a fair industrial relations environment."

Die Konstitusionele Hof het derhalwe nie alleen uitdruklik erkenning verleen aan die reg op kollektiewe bedinging nie, maar verwys daarna as 'n reg, soortgelyk aan ander organisatoriese regte sonder om dit as 'n blote "vryheid" af te water, 'n reg om 'n vakbond te stig en om aan stakings deel te neem.

\section{SA National Defence Union v Minister of Defence}

\section{Inleidend}

Soos voorheen verduidelik, is daar verskillende uitsprake in hierdie onverkwiklike arbeidsdispuut gelewer. Die sleutelvraagstuk waaroor telkens in onderskeie uitsprake ten opsigte van kollektiewe bedinging uitsluitsel gegee moes word, was "whether there is a legally enforceable duty on the SADF ('employer') to engage in collective bargaining with SANDU, a military trade union that was recently permitted to function as such" (per Conradie JA in SANDU $v$ Minister of Defence; Minister of Defence $v$ SANDU [2006] 11 BLLR 1043 (HHA) 1045H). 
In die Hoogste Hof van Appél in SANDU v Minister of Defence; Minister of Defence $v$ SANDU (supra) het appélregter Conradie verklaar dat artikel 23(5) van die Grondwet vir meer as een uitleg vatbaar is en dat die riglyne vervat in artikel 39 van die Grondwet derhalwe aangelê moet word by die uitleg van die onderhawige artikel. Die Hof wend hom tot internasionale instrumente en konvensies ten einde die onderhawige artikel uit te lê.

Die Hof stem egter nie saam met die uitspraak van die Hof a quo in SANDU I dat die verskil in bewoording van die finale Grondwet van dergelike bewoording in die interim Grondwet regtens beteken dat in laasgenoemde geval daar inderdaad 'n reg op kollektiewe bedinging bestaan het terwyl in eersgenoemde geval daar nie so 'n reg bestaan nie. Volgens die Hof, na my mening tereg ook, is die formuleringsverskil ("change of expression") van geen besondere arbeidsregtelike betekenis is nie (1051G-1052B). Die Hof verklaar dat die verste wat die wetgewer wel bereid is om te gaan, is in die geval van 'n weiering om te beding ("to negotiate") wanneer bepaalde voorgeskrewe vereistes eers ingevolge artikel 64(2) nagekom moet word, alvorens gestaak kan word: "Advisory arbitration is a compulsory pre-strike procedure in disputes over the 'duty' to bargain. The arbitration is not determinative of the dispute. It binds neither party. It merely helps them find a solution. This is the clearest indication that the LRA does not recognise a duty to bargain enforceable by the courts" (1053A-B).

Hierdie gevolgtrekking van die Hof is omstrede. Hoe kan 'n bedingingsdispuut tot oplossing gebring word as 'n adviserende arbitrasietoekenning, vir watter rede ook al, nie verkry kan word nie of ontaard in 'n uitgerekte litigasieproses na maande en jare?

\section{Beslissing van Konstitusionele Hof}

Die vraag rakende die reg om kollektief te beding het ook in die Konstitusionale Hof aandag ontvang, maar ongelukkig op 'n sekondêre basis (Coin Security Franchises and National Bargaining Council for the Road Freight Industry 2007 ILJ 2623 (KH)). Die sleutelprobleme in die onderhawige saak, is op 'n "insiggewende wyse" vanuit 'n ander hoek as die bestaan of nie van 'n reg op kollektiewe bedinging benader en uiteindelik bereg.

Die Konstitusionele Hof het, by monde van regter O'Regan, daarop gewys dat in bogemelde uitsprake in die howe a quo, die bespreking van die onderskeie dispute telkens begin is met die betekenis van artikel 23(5) van die Grondwet en of dit regtens 'n reg om te onderhandel, verleen. Die Hof was van mening dat dit nie die korrekte vertrekpunt was nie (vir die betrokke redes sien par 50-54; en Van Jaarsveld 2008 THRHR 124).

Die sienswyse van die Hof is andersins ten aansien van reg op kollektiewe bedinging egter besonder betekenisvol wanneer onder ander verklaar word:

"It is clear that at the minimum section 23(5) confers a right on trade unions, employers' organisations and employers to engage in collective bargaining that may not be abolished by the legislature, unless it can be shown that such abolition passes the test for justification established in section 36 of the Constitution. In recognising this, we should remember that in the past, black 
workers and trade unions that represented them were prohibited from engaging in collective bargaining. Preventing a recurrence of this historical injustice is one of the purposes of section 23(5)" (par 50, my kursivering).

In hierdie paragraaf identifiseer die Hof na my mening die volgende drie belangrike komponente in verband met die betekenis van artikel 23(5) van die Grondwet, naamlik:

(a) Op die minste verleen artikel 23(5) aan vakbonde, werkgewersorganisasies en werkgewers 'n reg om aan kollekteiwe bedinging deel te neem. Hiermee word die standpunt dat artikel 23(5) slegs 'n vryheid en nie reg tot kollektiewe bedinging nie, finaal verwerp - soos wat die Hoogste Hof van Appél ook vroeër gedoen het (sien SANDU IV [2006] 11 BLLR 1043 (HHA); contra: Cheadle, Davis and Haysom South African Constitutional Law: The Bill of Rights 390-395; SANDU 12003 ILJ 1495 (T); en Vettori 2005 De Jure 382).

(b) Wanneer hierdie reg erken word, moet die historiese aanloop daartoe ook in gedagte gehou word, naamlik dat swart werkers en hulle vakbonde in die verlede verbied is om aan kollektiewe bedinging deel te neem. Ek het reeds eerder betoog dat die reg op kollektiewe bedinging in historiese konteks beoordeel en verstaan moet word, en ook probeer aantoon dat beide die howe en skrywers met eentonige reëlmatig verklaar het dat die oogmerk van die reg op kollektiewe bedinging is om arbeidsonrus te vermy en arbeidsvrede te handhaaf (sien Van Jaarsveld 2007 THRHR 300-302) - welke oogmerk vandag nog na my mening onverminderd geld - veral so na die onlangse ontwrigtende arbeidsonrus in die myn- en landboubedrywe hier ter plaatse).

(c) Een van die oogmerke van artikel 23(5) is ook om 'n herhaling van hierdie historiese onreg ("injustice") te voorkom. As die vroeëre verbod op kollektiewe bedinging as 'n historiese onreg beskou is, dan des te meer moet enige ontkenning of afwatering van hierdie fundamentele konstitusionele reg tot die nikseggende, in ons nuwe demokratiese arbeidsbestel, ook as 'n onaanvaarbare arbeidsonreg beskou word.

Alhoewel die Konstitusionele Hof bereid was om 'n reg op kollektiewe bedinging te erken, was dit egter nie bereid om verder te gaan en inhoud en betekenis daaraan te verleen nie of te verklaar dat die teenkant daarvan inderdaad ' $n$ verpligting op die ander party plaas om te onderhandel nie. In dié verband het die Hof onder andere verklaar:

"Before turning to the subject matter of the regulations, it should be noted that were section 23(5) to establish a justiciable duty to bargain, enforceable by either employers or unions outside of a legislative framework to regulate that duty, courts may be drawn into a range of controversial, industrial-relations issues. These issues would include questions relating to the level at which bargaining should take place (ie at the level of the workplace, at the level of an enterprise, or at industry level); the level of union membership required to give rise to the duty; the topics of bargaining and the manner of bargaining" (par 55).

Die verpligting om te onderhandel met al sy vertakkings hoef egter nie so problematies en kompleks te wees soos wat die Hof voorhou nie, veral nie indien tussen die reg (en verpligting) op kollektiewe bedinging aan die eenkant en die bedingingstrukture, -vlakke, -onderwerpe en uitkomstes aan 
die ander kant, onderskei word nie. Eersgenoemde word deur artikel 23(5) van die Grondwet gereël en laasgenoemde deur die Wet op Arbeids-verhoudinge van 1995 wat vir bedingingsrade, statutêre rade, inplementering van kollektiewe ooreenkomste, ensovoorts voorsiening maak.

Dieselfde vraagstuk het hom ook onlangs in Europa en Kanada voorgedoen en is dit daarom gepas om die omstrede kwessie verder op ' $n$ regsvergelykende basis te bespreek.

\section{$7 \quad$ Regsvergelykende oorsig}

\section{$71 \quad$ Inleiding}

Gedurende 1949 het die Internasionale Arbeidsorganisasie in Konvensie 98 - (handelende oor die reg om te organiseer en kollektief te beding) bepaal dat aan die reg op kollektiewe bedinging beslag gegee moet word deur maatreëls, met inagneming van plaaslike omstandighede, wat voorsiening maak vir die aanmoediging en bevordering van die ontwikkeling en benutting van vrywillige bedingingsmeganismes tussen werkgewers- en werknemersorganisasies sodat diensvoorwaardes en werksomstandighede by wyse van kollektiewe ooreenkomste bepaal kan word.

'n Soortgelyke aanbeveling is ook in die Recommendation on Collective Bargaining 163 van 1981 deur die IAO aanvaar (sien ook Potgieter "Die Reg op Kollektiewe Bedinging - 'n Internasionale Perspektief" 1994 TSAR 177; en Van Jaarsveld et al Principles and Practice of Labour Law par 538). In die bepalings van die Konvensie oor Kollektiewe Bedinging van 1981 is veral artikel 5 ook van besondere belang, wat onder andere bepaal:

"1. Measures adapted to national conditions shall be taken to promote collective bargaining.

2. The aims of the measures referred to in paragraph 1 of the Article shall be the following:

(a) collective bargaining should be made possible for all employers and all groups of workers in the branches of activity covered by this Convention."

Die Europese Gemeenskap se Gemeenskapshandves van 1989 maak ook voorsiening vir die reg op kollektiewe bedinging en die sluiting van kollektiewe ooreenkomste (A 17). Ten einde inhoud aan voormelde reg te gee, word werknemers se reg op inligting, raadpleging en deelname ook erken (A 7; en sien ook Potgieter 1994 TSAR 177). Insgelyks is artikel 11 van die Europese Konvensie vir Menseregte en Fundamentele Vryhede in Europese konteks ook van sleutelbelang, aangesien dit die vryheid van assosiasie beskerm en ook later die grondslag gevorm het vir rigtinggewende uitsprake in Europa gedurende 2008 (sien par 73 hieronder).

Macklem ("The Right to Bargain Collectively in International Law: Workers' Rights, Human Right, International Right?" in Labour Rights as Human Rights (2005) 74ev) het daarop gewys dat die betekenis van die reg op kollektiewe bedinging soos vervat in internasionale instrumente van die $\mathrm{IAO}$, Europese Unie en VN verskuif het van 'n reg wat bloot aangemoedig en bevorder moet word, na 'n meer substantiewe en omvattende 
bedingingsreg as gevolg van 'n resente arbeidsregtelike sleuteluitspraak. In Wilson v United Kingdom (2002 35 EHRR 409) het die Europese Hof vir Menseregte, volgens Macklem, beslis dat artikel artikel 11 van die Europese Konvensie van Menseregte:

\begin{abstract}
"does not necessarily protect all the features of a statutory collective bargaining regime, including a duty on employers to negotiate in good faith. But Article 11 imposes on an employer other duties contemplated by a right to bargain collectively, such as a duty to listen to collective representations, which in turn implies an obligation to establish a forum or process in which such representations can be made, and a duty not to interfere with a union's capacity to make representations on behalf of its members. Wilson thus is consistent with the more general trend of international human rights law towards enhanced protection of collective bargaining."
\end{abstract}

Die Wilson-uitspraak is ook deur Ewing beskryf "as probably the most important labour law decision for at least a generation" (2003 13 ILJ (UK) 20). Van besondere belang is natuurlik die verpligtinge van 'n werkgewer ten aansien van kollektiewe bedinging wat in die Wilson-uitspraak geïdentifiseer word.

Derhalwe het die arbeidsregtelike bedeling ten opsigte van kollektiewe bedinging in Europa gedurende 2005 die bestaan van 'n "general trend in ... human rights law towards enhanced protection of collective bargaining" erken. Hierdie vooruitskouings en standpunte van Macklem en Ewing het slegs enkele jare hierna in beide Kanada en Europa dramaties beslag ontvang in twee sleuteluitsprake wat onafhanklik en onwetend van mekaar, gedurende dieselfde tydspektrum gelewer is.

\title{
72 Regsposisie in Kanada
}

Gedurende 2007, interessant genoeg, het wesenlik dieselfde kollektiewe bedingingsprobleme hulle in die "Supreme Court of Canada" voorgedoen. In Health Services and Support-Facilities Subsector v Bargaining Association v British Columbia ([2007] 2 SCR 391, 2007 SCC 27 (Can)) moes die Hof beslis of die vryheid van assosiasie die reg ingesluit het om deel te neem aan kollektiewe bedinging ingevolge artikels 2(d) en 2(b) van die Kanadese "Charter of Rights and Freedoms".

Die feite was kortliks die volgende: Gedurende 2002 het die provinsiale regering van British Columbia nuwe wetgewing aanvaar wat belangrike bepalings in kollektiewe ooreenkomste vir gesondheidsorg-werknemers beperk het - bepalings in verband met regte oor die hertoedeling van werknemers, uitkontraktering, aflegging van werknemers en opvolging ondehandelinge, ensovoorts. Die wetgewing is oorhaastig sonder enige vooraf oorlegpleging met vakbonde deurgevoer. Hierop het die betrokke vakbonde die geldigheid van die wysigings betwis op grond daarvan dat dit artikel 2(d) van die "Charter" skend. Hulle het ook 'n klag by die Internasionale Arbeidsorganisasie geliasseer omdat die betrokke wysigings Konvensie 87 van die IAO na bewering geskend het. Etherington het aangevoer dat die betrokke wetgewing effektiewelik enige sinvolle kollektiewe bedinging oor ' $n$ aantal belangrike aangeleenthede uitgesluit het ("The BC Health Services and Support Decision - The Constitutionalization of a Right to Bargain Collectively in Canada" 2009 30(4) Comparative Labor Law 
\& Policy Journal 715). Die aansoek van die vakbonde is egter deur die laer howe van die hand gewys.

Die "Supreme Court of Canada" het hierteenoor besluit om die vryheid van assosiasie, soos bepaal in die "Charter", dermate uit te brei dat dit 'n reg op kollektiewe bedinging insluit. Die hof het verskeie redes aangevoer waarom laasgenoemde reg ten volle erken moes word en nie bloot 'n grondwetlike reg sonder enige betekenisvolle regte en verpligtinge moes wees nie (soos wat tans die posisie in Suid-Afrika is). Die Hof het verduidelik dat die redes waarom hierdie reg voorheen ontken is, nie meer geldig was nie en dat die reg nie bloot ' $n$ moderne reg was wat deur wetgewing daargestel is nie, maar 'n fundamentele vryheid was wat 'n lang arbeidsgeskiedenis deurloop het (par 25). Die Hof verklaar ook dat dit verkeerd was om vroeër beskerming aan hierdie belangrike kollektiewe reg te ontsê op grond daarvan dat dit die uitkomstes van kollektiewe bedinging sou beskerm. Die Hof stem saam dat die reg nie aangewend moet word om substantiewe uitkomstes te beskerm nie, maar eerder kollektiewe bedinging as 'n prosedure, wat duidelik van die finale uitkomste onderskeibaar was (par 29).

'n Ander belangrike oorweging wat die Hof aangevoer het, was dat die beskerming van ' $n$ reg op kollektiewe bedinging ingevolge die Kanadese "Charter", in ooreenstemming met ander regte, vryhede en waardes van die "Charter" was en dit het ook die ongelykheid in die werksplek aangespreek (par 20 en 82). Die Hof verklaar ook dat die reg op kollektiewe bedinging ' $n$ integrale deel van vryheid van assosiasie in die Internasionale Reg vorm (par 69). Oor die uitwerking van Internasionale Reg op die uitleg van regte en vryhede, soos vervat in die "Charter", verklaar die Hof as volg:

"[T]he Charter, as a living document, grows with society and speaks to the current situation and needs of Canadians. Thus Canada's current international law commitments and the current state of international thought on human rights provide a persuasive source of interpreting the scope of the Charter" (par 70).

Die Hof verwys dan ook na drie internasionale instrumente (nl. die IAO Konvensie no 87, die Internasionale Konvensie tov Siviele en Politieke Regte en die Internasionale Konvensie tov Ekonomiese, Sosiale en Kulturele Regte wat op Kanada van toepassing is (op 9 Julie 1948, 16 Desember 1966 en 15 Desember 1966 onderskeidelik toepaslik gemaak). Met die uitleg van hierdie instrumente, het die Hof bevind dat hulle in Kanada sowel as internasionaal, so geïnterpreteer word dat daar in die Internasionale Reg inderdaad 'n reg op kollektiewe bedinging bestaan en dat dieselfde reg ook ingevolge artikel 2(d) van die Kanadese "Charter" erken moet word (BC Health Services \& Support par 89). Vervolgens bespreek die Hof ook die bestek en aard van die reg en vervolg dan:

"Section 2(d) [of the Charter] does not guarantee the particular objectives sought through this association activity. However, it guarantees the process through which those goals are pursued. It means that employees have the right to unite, to present demands to health sector employers collectively and to engage in discussions in an attempt to achieve workplace-related goals. Section 2(d) imposes corresponding duties on government employers to agree to meet and discuss with them ... Thus the employees' right to collective bargaining imposes corresponding duties on the employer. It 
requires both employer and employees to meet and to bargain in good faith, in the pursuit of a common goal of peaceful and productive accommodation" (par 90).

Die $B C$ Health Service-uitspraak is wyd aanvaar alhoewel dit ook aan kritiek blootgestel is (sien Etherington 20, asook Langille "Can We Rely on the ILO?" 2008 CAN LAB \& EMP LJ 363; Fudge "The Supreme Court of Canada and the Right to Bargain Collectively" 2008 ILJ (UK) 35; en Adams "The Supreme Court, Collective Bargaining and International Law" 2008 CAN LAB \& EMP LJ 317).

Samevattend is die posisie in Kanada dus dat die reg op kollektiewe bedinging deur die "Charter" erken word, wat 'n verpligting op beide werkgewer en werknemer plaas om in goeie trou te onderhandel oor werksaangeleenthede, maar die uitkomste daarvan aan die betrokke partye se bedingingskrag, of gebrek daaraan, oor te laat.

\section{Posisie in Europese Unie}

Dieselfde probleem, soos hierbo verduidelik ten opsigte van Kanada, het hom in die Europese Hof vir Menseregte in die saak van Demir \& Baykara v Turkey, (Application no 34503/97, 21 Nov 2006) voorgedoen, toe die Hof moes besluit of die reg om kollektief te beding en om kollektiewe ooreenkomste te sluit, essensiële elemente van die reg op vryheid op assosiasie ingevolge artikel 11 van die Europese Konvensie op Menseregte en Fundamentele Vryheid behels - onbewus van die BC Health Servicesbeslissing (sien par 72 hierbo) omtrent ' $n$ jaar vroeër in Kanada.

'n Turkse vakbond van staatsamptenare (TBS) het met 'n stadsraad (GMC) 'n kollektiewe ooreenkoms wat die belangrikste diensvoorwaardes bevat het, vir 'n periode van 2 jaar gesluit. 'n Paar maande later, het GMC egter versuim om sekere bepalings van die ooreenkoms na te kom, waarop ene Baykara en Demir, albei senior lede van TBS, suksesvol 'n siviele geding teen die stadsraad (GMC) in 'n plaaslike hof ingestel het. Op appél egter, die beslissing is ter syde gestel, die kollektiewe ooreenkoms ongeldig verklaar en moes die werknemers die voordele wat hulle ingevolge die ongeldige ooreenkoms ontvang het, terugbetaal. Hierop het die vakbond die dispuut na die Europese Hof vir Menseregte verwys en aangevoer dat sy regte ingevolge artikel 11 (vryheid van assosiasie) van die Europese Konvensie op Menseregte en Fundamentele Vryhede geskend is. Die Europese Hof het bevestig dat daar 'n skending van artikel 11 deur die stadsraad (GMC) plaasgevind het waarop die werkgewer na die "Grand Chamber" van die Europese Hof geappelleer het.

Die "Grand Chamber" het gedurende 2008 eenparig beslis dat artikel 11 inderdaad deur die stadsraad verbreek is as gevolg van die ongeldigverklaring van die kollektiewe ooreenkoms wat gesluit is tussen die partye na kollektiewe bedinging tussen hulle. Met verwysing na die Engelse gewysdes van Wilson $v$ United Kingdom (supra) en ASLEF $v$ United Kingdom, ([2007] IRLR 361) internasionale instrumente, (par 98-101, 147151) en praktyke van Europese state, beslis die Europese Hof van Menseregte ten slotte dat: 
"the right to bargain collectively with the employer has in principle, become one of the essential elements of the right to form and to join trade unions for the protection of [one's] interest forth in Article 11 of the Convention, it being understood that States remain free to organise their system so as, if appropriate, to grant special status to representative trade unions" (par 154).

Die Europese skrywers Ewing en Hendry ("The Dramatic Implications of Demir and Baykara" 2010 ILJ (UK) 6 fn 13) verklaar dat die beslissing in die Demir and Baykara-saak (supra) 'n spieëlbeeld van die vroeëre Kanadese saak van $B C$ Health Services and Support-Facilities (supra) is, identiese beslissings wat onafhanklik van mekaar deur twee hoog aangeskrewe howe bereik is. Hulle sluit dan af:

"Any suggestion that the ECTHR decision in Demir and Baykara is somehow a temporary aberration is of course demolished by the fact that this was the unanimous judgment of the 17 judges of the Grand Chamber following the unanimous judgment of the 7 judges of the second section ... and that it is precisely convergent with the landmark decision of the Supreme Court of Canada in the Health and Support-Facilities Subsector Bargaining case. The plea of Lord Hoffman ("The Universality of Human Rights" 2009 Judicial Studies Board Annual Lecture 19) that the ECTHR should not bother itself with domestic implementation of the convention, is irrelevant to such monumental pronouncements of principles" (48).

\section{Regsposisie in Australië}

In Australië het kollektiewe bedinging, en meer spesifiek die reg op kollektiewe bedinging, baie dieselde ontwikkelingsgang as die in Suid-Afrika ervaar. Aanvanklik het die reg ten volle gegeld met die meegaande verpligting op ' $n$ werkgewer om wel kollektief te beding (probleme is egter tov gelding van die reg deur die howe uitgewys: sien, oa, Community \& Public Sector Union v Australian Broadcasting Corp (1995) 36 AILR 419; en Asahe Diamond Industrial Australia Pty Ltd v Automotive Food, Metal \& Engineering Union (1995) 59 IR 385). Maar gedurende 1996 het 'n koalisieregering van die Howard-Bondgenootskap deur wysigende wetgewing die stelsel van bona fide kollektiewe bedinging deur 'n bedeling van statutêre indiwiduele ooreenkomste, feitlik aan bande gelê (sien Workplace Relations and Other Legislation Amendment Act of 1996 asook R McCallum "Australian Workplace Agreements" 1997 AJIL 50). Die posisie is egter gedurende 2008 weer dramaties gewysig, toe die nuwe Arbeiders-regering die "Fair Work Bill 2008" gepubliseer het (sien in algemeen Forsyth in Forsyth and Stewart Fair Work (2009) 121-125).

Laasgenoemde wetsontwerp het gedurende 2009 op die Fair Work Act van 2009 uitgeloop. Die ou bedeling van die reg op kollektiewe bedinging is herstel deurdat weer eens voorsiening gemaak is vir die beginsels van "majority employee support" en bona fide bedinging. Ingevolge artikel 228 van hierdie Wet beteken "goedertrou-onderhandelinge" onder andere: "refraining from capricious or unfair conduct that undermines the freedom of association or collective bargaining" (art 228(1)(e)). Die praktiese betekenis van hierdie reg ingevolge Fair Work Act van 2009 is by geleentheid as volg verduidelik:

"While most bargaining would be voluntary, an element of compulsion would arise from the important principle that if a majority of employees at a 
workplace want to bargain collectively, their employer will be required to bargain collectively with them in good faith" (sien Forsyth Fair Work 126; asook "Forward with Fairness" beleidsdokument van Arbeidersparty p 14 van 2007).

\section{$8 \quad$ Kommentaar en slotsienswyse}

Die vraag ontstaan nou waar bevind ons ons regtens met betrekking tot artikel 23(5) van die Grondwet - veral in die lig van die volgende dictum van die Konstitusionele Hof in (SA National Defence Union v Minister of Defence supra) waarmee die bespreking oor die aangeleentheid afgesluit is:

"As I have held, however, it is not necessary to determine the proper interpretation of section 23(5) in this case and we accordingly refrain from doing so. Accordingly, we neither endorse nor reject the approach to section 23(5) of the Constitution adopted by the Supreme Court of Appeal" (par 56).

Hieruit is dit duidelik dat die deur wawyd oopgelaat is deur die Konstitusionale Hof vir toekomstige besinning en uitsluitsel oor die ware aard, betekenis en implikasies van die reg op kollektiewe bedinging. Daar is dan geen regverdiging vir die standpunt dat daar nie 'n reg op kollektiewe bedinging bestaan nie (sien in algemeen Grogan Collective Labour Law 92ev; Du Toit et al Labour Relations Law 244-245; Van Niekerk et al Law@Work 369-373; Van Jaarsveld, Fourie en Olivier Principles and Practice of Labour Law (2013) diensuitg 24 par 542). In twee onlangse beslissings (NEWU $v$ Leonard Dingler (Pty) Ltd [2011] 7 BLLR 706 (AH); SACCAWU \& Cash Crusaders [2011] 4 BALR 451 (CCMA)) oor die aangeleentheid, is ' $n$ interpretasie aan die statutêre bedeling gegee wat die Konstitusionele Hof (in SANDU v supra), nie bereid was om te gee nie terwyl dit blyk dat daar by 'n gewone uitleg van artikel 23(5) van die Grondwet (sien par 3 hierbo) prima facie wel so 'n reg bestaan. In SANDU V (par 50) verklaar die Konstitusionele hof:

"It is clear that at the minimum section 23(5) (of the Constitution) confers a right to trade unions, ... and employers to engage in collective bargaining ... (sien ook SAND // 2112D-F) alhoewel die Konstitusionele Hof tot dusver nie sy weg oopgesien het om inhoud aan die reg te verleen nie (sien SANDU $\mathrm{V}$ par 56).

Om aan 'n vakbond die reg te verleen om te mag assosieer en organisatoriese regte uit te oefen, maar dit die mees basiese vakbondreg te ontsê, naamlik om effektief kollektief te mag beding, is so goed as om aan ' $n$ persoon 'n motor sonder 'n enjin te verkoop - hy kan die voertuig slegs gebruik as daar telkens daadwerklike eksterne "bystand" verleen word. Verder, om die reg op kollektiewe bedinging te erken, maar te ontken dat daar ' $n$ meegaande verpligting op die ander party is om te beding, bestaan, maar dat die reg nietemin erken en verskans word deur die uitoefening van stakingsregte of verpligte arbitrasie (sien SANDU IV 1053A-B), is arbeidsregtelik nie logies, sinvol en in belang van harmonieuse arbeidsverhoudinge nie. Voorstanders van die standpunt, soos reeds daarop gewys, dat die Grondwet slegs vir 'n vryheid, en nie 'n reg op kollektiewe bedinging nie voorsiening maak, is egter self bereid om toe te gee dat die skeidslyn tussen die twee gevalle delikaat is en dat daar moontlik ruimte en meriete vir ' $n$ 
teenoorgestelde sienswyse is (sien Brassey en Cooper in Chaskalson et al Constitutional Law of South Africa 30).

Daar moet derhalwe voortdurend onderskei word tussen die fundamentele reg op kollektiewe bedinging, aan die een kant (wat verpligtend behoort te wees) en die meganismes, partye, onderwerpe en uitkomstes van bedinging, aan die ander kant, wat algeheel vrywillig is. Die onderhawige reg is ook nie absoluut nie en daarom moet ' $n$ party telkens aan bepaalde vereistes voldoen soos neergelê in die Wet op Arbeidsverhoudinge van 1995. Indien te doene gekry word met uitsonderlike gevalle soos van lede van die Weermag, kan die fundamentele reg ingevolge artikel 36 van die Grondwet aan sinvolle beperkings onderhewig gestel word sonder om die werking en toepassing daarvan totaal te neutraliseer of kragteloos te maak.

Die Konstitusionele Hof het op bepaalde praktiese probleme gewys indien 'n "justiciable duty to bargain" ingevolge artikel 23(5) van die Grondwet erken sou word (SANDU par 55 en sien ook weer par 64 hierbo). Die verpligting om te beding met al sy vertakkinge is egter nie so problematies en kompleks soos wat die Hof aangevoer het nie, veral nie as die reg (verpligting) op kollektiewe bedinging onderskei word van die bedingingstrukture, -vlakke en -onderwerpe, ensovoort. Eersgenoemde word gereguleer deur artikel 23(5) van die Grondwet en laasgenoemde deur die Wet op Arbeidsverhoudinge van 1995 wat voorsiening maak vir bedingingsrade, statutêre rade, die implementering van kollektiewe ooreenkomste, ensovoort. In casu maak die regulasies (hoofstuk XX) van die SuidAfrikaanse Weermag ruimskoots voorsiening vir 'n militêre bedingingsraad, die sluiting van kollektiewe ooreenkomste, 'n militêre arbitrasieraad, erkenningsaangeleenthede, registrasie van vakbonde, ensovoorts (par 55). Verder kan verklaar word dat die vrees van die Konstitusionele Hof om by moeilike en omstrede kwessies rakende die proses van bedinging, die vlak van bedinging verteenwoordingingsvereistes, betrokke te raak (sien par 55) nie as te ernstig beskou hoef te word nie. Gedurende die vroeë 1980's was die praktiese toepassing van hierdie reg ook in polemiese kleed gehul, maar vir die howe was dit vanaf 1988 tot 2003 egter nie meer 'n onhanteerbare probleem nie (sien ook In re Certification of the Constitution of the Republic of South Africa supra; NUMSA v Bader Bop (Pty) Ltd supra; en Van Jaarsveld 2007 THRHR 300-305). Gedurende 1990 het regter O'Regan die volgende uitlating in 'n bekende regstydskrif gemaak ("Possibilities for Worker Participation in Corporate Decision-Making" 1990 Acta Juridica 132):

\footnotetext{
"Collective bargaining, however, effective at some levels, does not challenge but probably strengthens traditional structures of authority within business enterprises ... Nevertheless, systems of worker participation in decisionmaking in capitalist economics in the West have only been successful at all when they have been introduced in an environment where there is a strong trade union movement."
}

$\mathrm{Na}$ my mening, kan hierdie denkrigting vandag nog steeds, na 20 jaar, ongekwalifiseerd onderskryf word. Daar is natuurlik nog 'n ander belangrike oorweging waarom 'n reg op kollektiewe bedinging met die meegaande verpligting op werkgewers om kollektief met vakbonde te beding, in die SuidAfrikaanse Arbeidsreg erken moet word, en dit is omdat die Wet op Arbeidsverhoudinge 1995 onbeskaamd in drie gevalle, mutatis mutandis, 
alreeds so 'n reg erken met 'n kollaterale verpligting op 'n werkgewer, naamlik:

(a) Artikel 189(2) bepaal:

“(2) The employer and the other consulting parties must in the consultation envisaged by subsection (1) and (3) engage in a meaningful joint consensusseeking process and attempt to reach consensus on ..."

(b) Artikel 84(1) verklaar:

"A workplace forum is entitled to be consulted by the employer about proposals relating to any of the following matters ..."

(c) Artikel 86(1) bepaal:

"an employer must consult and reach consensus with a workplace forum before implementing any proposal concerning ..."

As die wetgewer in bogenoemde gevalle nie enige praktiese probleme in die afdwinging van bogemelde konsensus-soekende statutêre prosedures voorsien het nie, waarom moet dit dan die situasie wees in die geval van die proses onder bespreking waar slegs 'n verpligting om deel te neem aan gesamentlike bona fide-kollektiewe bedinging (laat staan nog konsensus) vereis en verlang word (die klassieke verduideliking van Brassey ongeveer vyf-en-twintig jaar gelede (sien par 2 hierbo; en volgens die outeur se mening geld dit deesdae nog steeds). Ons arbeidsregtelike bedeling bevind hom regtens nou weer in dieselfde situasie as in 1989 toe Cameron ("Overview of the Industrial Court" in Benjamin, Jacobus and Albertyn Strikes, Lock-outs and Arbitration in SA Labour Law (1989) 17) hom in geen onsekere taal sterk as volg uitgelaat het nie:

"As an enforceable obligation in labour law this duty [to bargain in good faith] has now come of age in South Africa. After a promising start, the existence of the obligation was first denied and then attenuated by the court ... If the latest judgments set the tone for future decisions - and there is no reason to believe that they will not - the court will in effect have adopted the full doctrine of obligatory negotiation in good faith with representative bargaining parties."

Ten slotte, as kollektiewe bedinging dan in die verlede die wyse was waarop arbeidswanverhoudinge en -dispute besweer is, en as kollektiewe bedinging die hartslag van gesonde arbeidsverhoudinge was en die hoeksteen daarvan gevorm het (sien Buffelsfontein GMC-saak supra), en as die reg op bona fide-kollektiewe bedinging in sy volheid in die hedendaagse Europa, Kanada en Australië erken word, (contra: Du Toit et al Labour Relations Law 244-245) en as dit blyk dat sodanige bedinging moontlik die angel uit die "brave and boisterous battles" (sien inleidende paragraaf 1ste bladsy) tussen werkers en werkgewers in die myn- en landbou-bedryf, kan haal, is dit onduidelik en onverstaanbaar waarom daar soveel weerstandigheid teen die afdwingbaarheid van hierdie nou internasionaal-erkende fundamentele reg bestaan (sien in algemeen Van Niekerk et al Law@Work 369-373).

Gedagtig aan die aard en dinamiese rol van die konsep van kollektiewe bedinging, moet die volgende toepaslike versugting van regter Sachs 
mutatis mutandis in gedagte gehou word toe hy hom in SA National Defence Union v Minister of Defence (supra 2285G-I) soos volg uitlaat het:

"Nor, conversely, do I feel it appropriate in this matter to grapple with the possible implications of what would at first sight seem to be the relative ease with which some or all of these rights could be subjected to extensive limitation, thereby suggesting that they could be imbued at their core with a fragility and relativism out of keeping with their hard-won, resilient and firmly entrenched character."

Fanie van Jaarsveld Universiteit van Pretoria 